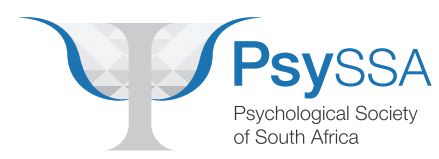

\title{
What antiracist psychology does and does not (do)
}

\section{Kopano Ratele ${ }^{1,2}$ (iD and Nick Malherbe ${ }^{1,2}$}

On 16 August 2012, South African security forces shot down 112 Black miners employed by Lonmin platinum mine in Marikana, North West Province. Thirty-four Black men were killed and 78 were injured. Most of the security forces were also Black men. The world came to see the massacre on television. Cyril Ramaphosa - who was, at the time, the deputy president of South Africa and on the board of Lonmin - characterised the miners' demands for decent wages and improved working conditions as a dastardly, criminal act that had to be met with force (Davies, 2015; Essa, 2018; Farlam et al., 2015). For many, Ramaphosa's apology 5 years later rang hollow.

On 25 May 2020, a White police officer, Derek Chauvin, killed George Floyd by kneeling on his neck for over $8 \mathrm{~min}$. Floyd was murdered in Minneapolis, in the United States, during an arrest for allegedly using a counterfeit bill (Deliso, 2020). Three other police officers stood by and watched. Floyd, who repeatedly begged for his life, and continually called out 'I can't breathe, I can't breathe', was publicly murdered while handcuffed, his face down on the tarmac. Bystanders filmed this, and the world watched the murder of this 46-year-old African-American man on their television and phone screens. There is no question that racism undergirded the police brutality that killed Floyd and it was for this reason that his murder ignited a wave of protests in the United States. The demands of protesters for racial justice reached unprecedented levels. Since Floyd's death, we have witnessed many protests in solidarity with the Movement for Black Lives in many different countries (Hagemann \& Jeffery, 2020).

The public lynching of one Black man in the United States ignited a very different public response to the killing of 34 Black men in South Africa. Indeed, the outrage over Floyd's murder was successfully and inspirationally harnessed into global demonstrations against racism, whereas the Marikana massacre, sadly, did not yield as great a response. Those committed to anti-racist struggle must learn from both of these cases, and others like them. Anti-racist struggle needs to be expansive and internationalist if it is to destroy the apparatuses through which racism worked to cheapen, and ultimately end the lives of George Floyd, the miners of Marikana, and so many others.

\footnotetext{
'Institute for Social and Health Sciences, University of South Africa, South Africa

${ }^{2}$ South African Medical Research Council, University of South Africa Masculinity and Health Research Unit, South Africa 


\section{Anti-racism work necessitates work and risk}

All anti-establishment struggles - which, of course, include anti-racist struggles - necessitate risk. Throughout history, imprisonment, torture, surveillance, banning, deportation, exile, and death have loomed large over those who have committed themselves to anti-establishment struggle. This, too, is the case for those who commit themselves to eradicating racist systems, institutions, laws, and rules. We saw this risk play out in the militant crowds which gathered, all over the world, to demand racial justice in the wake of Floyd's murder. These crowds gathered in the face of the COVID-19 pandemic, while facing horrific levels of police brutality (Ransby, 2020). These crowds, and those like them, are rejecting not only racism but also the entire racist social apparatus upon which capitalist exploitation, the prison industrial complex, patriarchy, imperialism, and ecological devastation depend (Davis, 2016). Indeed, racism is always entwined with other forms of direct and indirect violence, exploitation, and injustice. A commitment to anti-racism is, therefore, a 'refusal to accept the present as definitive' (Fanon, 1967/2008, p. 176). An ambitious and utterly vital risk if ever there was one.

A message to psychologists and psychology students: fighting racism, along with the risk of participating in anti-racism struggles, has always been led by, and has fallen upon, grassroots activism, and not psychology. This is not to say that psychologists and psychology students have not been involved in anti-racist struggle. It is, however, to point out that psychology, in the main, has been of relatively little use, or has made itself superfluous, to this struggle. In fact, psychology has oftentimes worked against anti-racist struggle, as was the case in colonial India, Nazi Germany, the United States, and apartheid South Africa (Dawes, 1985; Geuter, 1992; Hartnack, 1987). Although most contemporary psychological practice is likely to disavow racism, anti-racist psychology remains marginal. For instance, Bhatia and Priya (2018) explain that although psychologists are oftentimes tasked with running racial sensitivity workshops and seminars, their treatment of racism tends to ignore structural inequalities, neoliberal capitalism, patriarchy, and even mental health issues. Racism, in other words, is made to seem like a matter of cultural incongruence, ignorance, or personality, which can be addressed through diversity training, contact, and tolerant attitudes. A psychology of this sort ignores struggle, and thus circumvents the work and risk required for anti-racism.

There is, however, also a rich literature on the decolonising, anti-racist potential of psychology (see, e.g., Bhatia \& Priya, 2018; Cooper \& Ratele, 2018; Fanon, 1967/2008; Ratele, 2019; Seedat \& Suffla, 2017). Taking our leave from this literature, we see our task being to remind, call attention to, and highlight for psychologists, psychology students, and interested readers beyond the discipline, a psychology that embraces the work and risk of anti-racism struggle by abandoning epistemic restrictions and methodological fidelity. In other words, we pose the possibility of a psychology that is more concerned with those struggling against the psychological and material pervasiveness of racism, than it is with disciplinary orthodoxy (see Cooper \& Ratele, 2018; Ngũgĩ, 1986).

\section{Lessons of anti-racism are best learned outside of the classroom}

Some psychologists have recognised the challenges involved with teaching and working towards antiracism (see, e.g., Ahmed, 2008; Boatright-Horowitz, 2005). Perhaps, though, the 'lesson' of anti-racism is best learned outside of the classroom, within the context of organised, intersectional, Black-led collective struggle (Ransby, 2020). When acting collectively towards anti-racist objectives, the racist ego ideal becomes dismantled not for egoistic reasons, but for political ones. Here, the psychologist may play a role in working with people, as part of the process of unlearning racism, to articulate it for themselves and for others, and to construct anti-racist policies, institutions, and structures. As such, this articulation should go beyond merely recognising and condemning that which is racist (Durrheim et al., 
2011). Indeed, what is required is the more difficult work of rejecting racist acts and policies which hold supremacist whiteness up as an ideological standard, and that support the racist social apparatus (Davis, 2016; Fanon, 1967/2008). Thus, for the anti-racist who identifies as White, calling out racist acts and policies does not serve as performative allyship or cathartic self-flagellation. For the Black person, Blackness does not make one an anti-racist, and waiting to personally experience racism to join antiracist struggles in effect perpetuates the racist status quo. Rather, both the Black and the White subject must identify manifestations of racism within the self, others and the world as an unbearable truth that can and must be fought by us, as individuals, although it can only be completely eradicated through organised, intersectional, Black-led collective struggle. As Davis (2016) argues, forging solidarities depends not on merely recognising the struggles of another, but on understanding these struggles as one's own. In this regard, anti-racist psychology dislodges psychology's preoccupation with the individual (as the centre of the universe) by engaging anti-racism not as a modality of self-improvement, but as a political imperative that holds individuals accountable to a collective project of liberation.

Because psychological liberation serves as a key correlative for political liberation (Cooper \& Ratele, 2018), anti-racism must also operate beyond politically charged moments of collective resistance. Accordingly, anti-racist psychology should concern itself with the routine, material lives of persons and groups. Indeed, anti-racism demands from us a commitment to addressing racism in our daily lives (e.g., micro-aggressions, colonial public monuments, and coded language). For psychologists, this means working with people to acknowledge and take seriously how personal experiences shape - but are not entirely determined by - history (see Hook \& Howarth, 2005). We are always affected by social structures, but we can change how these structures affect us. Here, anti-racist psychology works to honour Fanon's well-known maxim: 'I am my own foundation. And it is by going beyond the historical, instrumental hypothesis that I will initiate the cycle of my freedom' (Fanon, 1967/2008, p. 180). One need not forgive, nor seek to collaborate with, those who continue to benefit from the racist social apparatus. The point, instead, is to realise one's own agency (i.e., become one's own foundation) through rejecting habitual iterations of racism, asserting the dignity of the racially oppressed within the everyday, and altering racist culture so that we might transform racist structures (Cooper \& Ratele, 2018).

An anti-racist psychology takes an explicitly partisan political position, rejecting many of the racist systems upon which the discipline of psychology was founded, and through which the science and profession garnered legitimacy in White supremacist states in the 20th century (see Richards, 2010). At the same time, an anti-racist psychology rejects notions of the psychologist as the Master Knower. Psychologists are thus called to immerse themselves in and learn from collective anti-racist struggles and everyday anti-racist resistance, offering their skills whenever they are invited to do so. While these skills might have their basis in psychological training, if they are to be repurposed for anti-racism, they must be reconstituted through a range of other disciplines and emancipatory traditions (Hook \& Howarth, 2005). This is to say, in following on from the history of anti-racist movements, such as the Combahee River Collective, the Movement for Black Lives, the Black Panther Party, the Black Consciousness Movement, and Abahlali baseMjondolo, an antiracist psychology recognises that racism is always an intersectional issue, and therefore necessitates an ambitious scope.

\section{Anti-racist psychology seeks to bend psychology to the will of anti- racism}

Anti-racism, we hope to have made clear, does not embody a fixed set of criteria, steps, or aphorisms. Anti-racism is a set of ongoing acts and practical commitments. Thus, anti-racist psychology is, quite simply, an active, political commitment to the risk of anti-racist struggle and to 
Antiracist psychology does not:

1. Represent a psychological discipline or field;

2. Understand whiteness as monolithic or static;

3. Confine racism to the personality, ignorance, or attitudes of the individual;

4. Perceive racism as separate from other forms of social oppression;

5. Approach antiracism as a momentary act;

6. Believe racism to be of concern to some people and not others.

Figure I. What anti-racist psychology does not (do).

Antiracist psychology:

1. Offers an approach for practicing psychology;

2. Prioritises antiracism over psychology;

3. Understands racism as pervasive;

4. Engages the psychological, systemic and material constituents of racism;

5. Resists the seeming totality of the racist social apparatus;

6. Approaches antiracism as an everyday political commitment and through Black-led collective struggle;

7. Intersects with other social justice struggles;

8. Necessitates ongoing work and risk;

9. Entails accountability;

10. Considers antiracism as a project of human emancipation;

11. Reckons with psychology's historical reliance on the racist social apparatus;

12. Requires that psychologists and psychology students learn from, acknowledge and enunciate their own pasts and errors in an effort to repeatedly recommit themselves to antiracism.

Figure 2. What anti-racist psychology does.

working against racism. An anti-racist psychology student seeks out anti-racist literature, antiracist collectives, and joins in whatever ways they can in working against racist acts, cultures, policies, and structures. An anti-racist psychologist participates in working against racism through teaching, anti-racist mental health support, writing, and participating in anti-racist collectives. It is perhaps worth fleshing out what is meant by anti-racist psychology by ruminating on what it does, as well as what it does not do. Or, in the words of Ratele (2019), defining antiracist psychology via negation, or what it does not (do) (Figure 1), and affirmation, or what it does (Figure 2).

In short, anti-racist psychology seeks to bend psychology to the will of anti-racism, and never vice versa. It requires that psychologists work with people who take on the enormous risk of antiracism, a risk upon which humanity depends.

\section{Declaration of conflicting interests}

The author(s) declared no potential conflicts of interest with respect to the research, authorship, and/or publication of this article. 


\section{Funding}

The author(s) received no financial support for the research, authorship, and/or publication of this article.

\section{ORCID iD}

Kopano Ratele (iD https://orcid.org/0000-0002-1688-5136

\section{References}

Ahmed, B. (2008). Teaching critical psychology of 'race' issues: Problems in promoting anti-racist practice. Journal of Community \& Applied Social Psychology, 18(1), 54-67.

Bhatia, S., \& Priya, K. R. (2018). Decolonizing culture: Euro-American psychology and the shaping of neoliberal selves in India. Theory \& Psychology, 28(5), 645-668.

Boatright-Horowitz, S. L. (2005). Teaching antiracism in a large introductory psychology class: A course module and its evaluation. Journal of Black Studies, 36(1), 34-51.

Cooper, S., \& Ratele, K. (2018). The Black Consciousness psychology of Steve Biko. In S. Fernando \& R. Moodley (Eds.), Global psychologies: Mental health and the Global South (pp. 245-260). Palgrave Macmillan.

Davies, N. (2015, May 19). Marikana massacre: The untold story of the strike leader who died for workers' rights. The Guardian. https://www.theguardian.com/world/2015/may/19/marikana-massacre-untoldstory-strike-leader-died-workers-rights

Davis, A. Y. (2016). Freedom is a constant struggle: Ferguson, Palestine, and the foundations of a movement. Haymarket Books.

Dawes, A. (1985). Politics and mental health: The position of clinical psychology in South Africa. South African Journal of Psychology, 15(2), 55-61.

Deliso, M. (2020, June 10). Timeline: The impact of George Floyd's death in Minneapolis and beyond. $A B C$ News. https://abcnews.go.com/US/timeline-impact-george-floyds-death-minneapolis/story?id=70999322

Durrheim, K., Mtose, X., \& Brown, L. (2011). Race trouble: Race, identity and inequality in post-apartheid South Africa. Lexington Books.

Essa, A. (2018, August 16). Six years on, still no justice or closure for Marikana victims. Mail \& Guardian. https://mg.co.za/article/2018-08-16-six-years-on-still-no-justice-or-closure-for-marikana-victims/

Fanon, F. (2008). Black skin, white masks. Pluto Press. Original work published 1967.

Farlam, I. G., Hemraj, P. D., \& Tokota, B. R. (2015). Marikana commission of inquiry: Report on matters of public, national and international concern arising out of the tragic incidents at the Lonmin Mine in Marikana, in the North West Province. https:/www.sahrc.org.za/home/21/files/marikana-report-1.pdf

Geuter, U. (1992). The professionalization of psychology in Nazi Germany. Cambridge University Press.

Hagemann, H., \& Jeffery, L. (2020, May 31). George Floyd reverberates globally: Thousands protest in Germany, U.K., New Zealand. NPR. https://www.npr.org/2020/05/31/866428272/george-floyd-reverberates-globally-thousands-protest-in-germany-u-k-canada

Hartnack, C. (1987). British psychoanalysts in colonial India. In M. Ash \& W. Woodward (Eds.), Psychology in twentieth-century thought and society (pp. 233-252). Cambridge University Press.

Hook, D., \& Howarth, C. (2005). Future directions for a critical social psychology of racism/antiracism. Journal of Community \& Applied Social Psychology, 15(6), 506-512.

Ngũgĩ, wa Thiong'o. (1986). Decolonizing the mind: The politics of language in African literature. Currey.

Ransby, B. (2020, July 2). The white left needs to embrace Black leadership. The Nation. https://www.thenation.com/article/activism/Black-lives-white-left/

Ratele, K. (2019). The world looks this from here: Thoughts on African psychology. Wits University Press. Richards, G. (2010). Putting psychology in its place: Critical historical perspectives (3rd ed.). Routledge.

Seedat, M., \& Suffla, S. (2017). Community psychology and its (dis) contents, archival legacies and decolonisation. South African Journal of Psychology, 47(4), 421-431. 